\title{
The Effect of Alkaline pH on Growth and Metabolic Products of a Motile, Yellow-pigmented Streptococcus sp.
}

\author{
By ANN F. GRAHAM AND BARBARA M. LUND* \\ ARC Food Research Institute, Colney Lane, Norwich NR4 7UA, U.K.
}

(Received 10 February 1983)

\begin{abstract}
Streptococcus BL 78/7 was isolated from alkaline potato-processing effluent, and resembled $S$. casseliflavus in morphology, motility and pigment. In aerobic conditions, at controlled $\mathrm{pH}$, growth occurred between $\mathrm{pH} 5$ and 11 with a maximum growth rate between $\mathrm{pH} 8$ and 9 and a maximum yield at $\mathrm{pH} 8$. The major metabolic products formed from glucose were lactate and acetate. The molar proportion of lactate to acetate decreased with increasing $\mathrm{pH}$, from $4: 1$ at $\mathrm{pH} 5$ to approximately $1: 1$ above $\mathrm{pH} \mathrm{9.} \mathrm{Growth} \mathrm{occurred} \mathrm{under} \mathrm{nitrogen} \mathrm{over} \mathrm{the} \mathrm{pH}$ range from below 6 to 11, with a maximum growth rate and yield at $\mathrm{pH} 7$ to 8 . Lactate was the major metabolic product, with formate, acetate and ethanol also present in the molar ratio of $2: 1: 1$. The molar proportion of lactate to formate decreased from $5: 1$ at $\mathrm{pH} 6$ to $1 \cdot 3: 1$ at $\mathrm{pH} 11$.
\end{abstract}

\section{INTRODUCTION}

The use of sodium hydroxide in the process of lye-peeling potatoes can result in the production of effluents with a pH of up to 12, which can be neutralized by bacterial fermentation (Gee et al., 1974; Sistrunk et al., 1979) but there is little information regarding the microbiology of the process. Several strains of bacteria that grow optimally at alkaline $\mathrm{pH}$ have been isolated by us from such wastes. These include five strains of a Streptococcus capable of relatively rapid growth at $\mathrm{pH} 10 \cdot 3$.

Although the ability to grow at $\mathrm{pH} 9.6$ is characteristic of group D streptococci, there is little published information on the effect of controlled $\mathrm{pH}$ in the alkaline region on the rate of growth and the metabolism of streptococci. Gunsalus \& Niven (1942) showed that when Streptococcus faecalis subsp. liquefaciens was grown anaerobically with the $\mathrm{pH}$ controlled at 5,7 and 9, the proportion of glucose metabolized to lactate was $92 \%$ at $\mathrm{pH} 5$ but decreased to $70 \%$ at $\mathrm{pH} 9$, lactate being replaced by formate, acetate and ethanol. Studies of the effect of $\mathrm{pH}$ in the region of $\mathrm{pH} 4$ to 8 on the metabolism of several species of Streptococcus and of Lactobacillus bulgaricus have been made by Platt \& Foster (1958) and Rhee \& Pack (1980).

The purpose of the present work was to determine the effect of alkaline $\mathrm{pH}$ on the rate of growth, the maximum cell density and the metabolic products of a Streptococcus isolated from alkaline potato-processing waste.

\section{METHODS}

Organism. Streptococcus strain BL $78 / 7$ was isolated at $20^{\circ} \mathrm{C}$ from a sample of potato waste, resulting from a commercial lye-peeling process, which had undergone a microbial fermentation and in which the $\mathrm{pH}$ had decreased to approximately $\mathrm{pH}$ 5. The isolate was obtained by enrichment in Medium 1 at $\mathrm{pH} 10$ to $10 \cdot 5$, purified by plating on solidified Medium 1 and maintained on slopes of same medium.

Media. Medium 1, used for maintenance of strain BL 78/7, contained $\left(\mathrm{g}^{-1}\right)$; peptone (Difco), 5 ; yeast extract (Difco), 1.5; glucose, $5 ; \mathrm{Na}_{2} \mathrm{HPO}_{4} .12 \mathrm{H}_{2} \mathrm{O}, 1 \cdot 5 ; \mathrm{NaCl}, 1 \cdot 5 ; \mathrm{Na}_{2} \mathrm{CO}_{3}, 5 \cdot 3$. A solution (100 ml) of $\mathrm{Na}_{2} \mathrm{CO}_{3}$ at 10 times the final concentration was autoclaved separately and added aseptically to $900 \mathrm{ml}$ of the autoclaved medium. The solid form of Medium 1 was made by the addition of New Zealand Agar $\left(15 \mathrm{~g}^{-1}\right)$. The $\mathrm{pH}$ was adjusted to between 10.8 and 11.0 with sterile $\mathrm{NaOH}(0.5 \mathrm{M})$ after autoclaving. 
Medium 2, used for studies of growth rates in fermenters, contained $\left(\mathrm{g}^{-1}\right)$ : tryptone (Difco), 10; yeast extract (Difco), 3.7; glucose, 5; $\mathrm{NaCl}, 2 \cdot 5 ; \mathrm{Na}_{2} \mathrm{CO}_{3}, 5 \cdot 3$. The $\mathrm{Na}_{2} \mathrm{CO}_{3}$ was prepared as for Medium 1, and the glucose was added in the form of a $20 \%(\mathrm{w} / \mathrm{v})$ solution which had been sterilized by filtration through a cellulose acetate filter $(0.22 \mu \mathrm{m}$ pore size, Millipore). Appropriate volumes of these solutions were added aseptically to the autoclaved basal medium in the fermenter. The $\mathrm{pH}$ was adjusted with sterile $\mathrm{NaOH}(5 \mathrm{M})$ or $\mathrm{HCl}(1 \mathrm{M})$. When Medium 2 was used at a $\mathrm{pH}$ value of 9 or less, the $\mathrm{Na}_{2} \mathrm{CO}_{3}$ content was reduced to $1 \cdot 1 \mathrm{~g} \mathrm{l}^{-1}$.

Characterization tests. The following tests suggested by Sherman (1937) and by Deibel \& Seeley (1974) for the differentiation of enterococci from other streptococci were made. 1 . Growth at $10^{\circ} \mathrm{C}$; 2 . Growth at $45^{\circ} \mathrm{C}$; 3. Growth in media containing $6.5 \%(\mathrm{w} / \mathrm{v}) \mathrm{NaCl} ; 4$. Growth in media containing $40 \%(\mathrm{v} / \mathrm{v})$ bile. The tests were carried out at an initial $\mathrm{pH}$ of 7 to $7 \cdot 5$, on strain BL78/7 and on reference strains of $S$. faecalis, $S$. faecium and $S$. casseliflavus using the media and methods of Barnes et al. (1956).

Lancefield precipitin test. Test organisms were grown in static culture for $48 \mathrm{~h}$ at $37^{\circ} \mathrm{C}$ in Medium A of Barnes et al. (1956). Antigen extract was prepared by the method of Shattock (1949), layered on to group D antiserum (Wellcome) in a narrow glass tube and observed for the formation of a white precipitin ring.

Fermentation of sugars. Tests were made in the medium of Deibel et al. (1963), modified as follows: $1.15 \mathrm{ml}^{-1}$ of a $0.2 \%(\mathrm{w} / \mathrm{v})$ solution of bromothymol blue was added; 2 . glucose was omitted, and raffinose or xylose was sterilized by filtration and added to a final concentration of $10 \mathrm{~g} \mathrm{l}^{-1}$. Control experiments used sterile distilled water in place of the sugar solution. Cultures grown for $18 \mathrm{~h}$ on slopes of Medium 1 were used to inoculate $10 \mathrm{ml}$ test medium and acid production was observed as a colour change from blue to yellow.

Studies of the effect of $\mathrm{pH}$ on growth. Strain BL 78/7 was grown in Medium 2 at controlled $\mathrm{pH}$ in batch culture using a modular fermenter (LH 500, LH Engineering Co., Stoke Poges, Bucks.). A culture volume of $800 \mathrm{ml}$ was used in a 1 litre vessel. For aerated cultures, air was pumped into the vessel at $800 \mathrm{ml} \mathrm{min}^{-1}$ with a stirrer speed of 1000 r.p.m., and for non-aerated cultures oxygen-free nitrogen was bubbled slowly through the medium with a stirrer speed of 500 r.p.m. All cultures were grown at $37^{\circ} \mathrm{C}$. Foaming was controlled by the automatic addition of a sterile $20 \%(\mathrm{v} / \mathrm{v})$ aqueous suspension of Silicone DC Antifoam RD emulsion (Hopkin \& Williams) and pH was controlled by the automatic addition of sterile $\mathrm{NaOH}(5 \mathrm{M})$ or $\mathrm{HCl}(1 \mathrm{M})$. The medium was inoculated with $40 \mathrm{ml}$ of a culture grown for $18 \mathrm{~h}$ in Medium 2 at an initial $\mathrm{pH}$ of approximately 9.8 . Samples (approximately $5 \mathrm{ml}$ ) were withdrawn from the fermenter at intervals of $30 \mathrm{~min}$, the $\mathrm{pH}$ measured using a separate $\mathrm{pH}$ meter and the absorbance measured at $680 \mathrm{~nm}$. The increase in $\log _{10} A_{680}$ was plotted against time, and the specific growth rate ( $\mu$ ) was determined from the slope of the graph. A calibration curve relating $A_{680}$ to dry weight of cells was prepared using cells grown to late-exponential phase at $\mathrm{pH} 9 \cdot 5$.

Chemical analyses. Samples were removed from the fermenter at the beginning of stationary phase, centrifuged $\left(10000 \mathrm{~g}\right.$ for $10 \mathrm{~min}$ at $\left.10^{\circ} \mathrm{C}\right)$ and the supernatants stored at $-20^{\circ} \mathrm{C}$ prior to analysis for glucose, volatile fatty acids and ethanol. Glucose was determined using the Glucose Oxidase test combination (Boehringer). Volatile fatty acids and lactate were determined by titration of acidified samples against tetrabutylammonium hydroxide, followed by preparation of benzyl esters and separation by GLC (Jones \& Kay, 1976). Chromatography conditions were as follows: column temperature was maintained at $80^{\circ} \mathrm{C}$ for $20 \mathrm{~min}$ then increased to $150{ }^{\circ} \mathrm{C}$ at a rate of

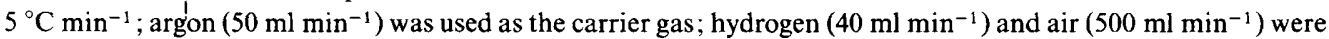
supplied to the detector; attenuation was between 200 and $10^{9}$. Reference acids $\left(10 \mu \mathrm{mol} \mathrm{ml}^{-1}\right)$ were treated in the same way as the samples, and crotonic acid was used as an internal standard.

Ethanol was determined by GLC using a PYE-104 instrument fitted with a flame-ionization detector. A $1 \mu l$ sample of the supernatant to be tested was injected on to a glass column $(1.5 \mathrm{~m} \times 6 \mathrm{~mm}$ o.d.) packed with Porapak Q (80-100 mesh, Waters Assoc. Inc., Mass., U.S.A.). Conditions were as follows: column temperature, $150^{\circ} \mathrm{C}$;

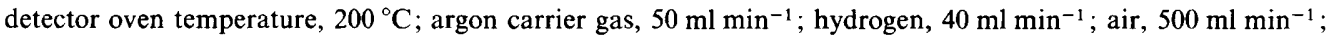
attenuation, $10^{9} / 100$. Samples $(1 \mu \mathrm{l})$ of a solution of ethanol $\left(10 \mu \mathrm{mol} \mathrm{ml}^{-1}\right)$ were used as a reference.

\section{RESULTS}

Properties of strain BL $78 / 7$

Strain BL $78 / 7$ was an elongated coccus, $1-2 \mu \mathrm{m}$ in length and $1 \mu \mathrm{m}$ in diameter, occurring in pairs or short chains. Motility was observed during the exponential phase of growth when grown aerobically in Medium 2 at $\mathrm{pH}$ values between 6 and 8 , but not when grown under nitrogen. After incubation for $48 \mathrm{~h}$ on Heart Infusion Agar (initial pH 7.4), cream/white colonies less than $1 \mathrm{~mm}$ in diameter were formed, whereas on Medium 1 (initial $\mathrm{pH} 10 \cdot 8$ ) colonies were yellow and greater than $1 \mathrm{~mm}$ in diameter. The properties shown in Table 1 indicated that strain BL 78/7 resembled $S$. casseliflavus. 
Table 1. Properties of isolate BL 78/7 and of reference strains of Streptococcus

\begin{tabular}{|c|c|c|c|c|c|c|}
\hline \multirow[b]{2}{*}{ Test* } & \multirow[b]{2}{*}{ Property } & \multirow{2}{*}{$\begin{array}{l}\text { S. faecalis } \\
\text { NCTC } 775\end{array}$} & \multirow{2}{*}{$\begin{array}{l}\text { S. faecium } \\
\text { NCTC 717I }\end{array}$} & \multicolumn{2}{|c|}{$S$ casseliflavus } & \multirow{2}{*}{$\begin{array}{c}\text { Strain } \\
\text { BL 78/7 }\end{array}$} \\
\hline & & & & ATCC 25788 & ATCC 25789 & \\
\hline 1 & Growth at $10^{\circ} \mathrm{C}$ & + & + & - & + & + \\
\hline 2 & Growth at $45^{\circ} \mathrm{C}$ & + & + & + & + & + \\
\hline 3 & $\begin{array}{l}\text { Growth in presence of } \\
6.5 \% \mathrm{NaCl}\end{array}$ & + & + & + & + & + \\
\hline 4 & $\begin{array}{l}\text { Growth in presence of } \\
40 \% \text { bile }\end{array}$ & + & + & + & + & + \\
\hline 5 & Lancefield group D & + & NT & - & + & + \\
\hline 6 & $\begin{array}{l}\text { Formation of acid from } \\
\text { raffinose }\end{array}$ & - & - & + & + & + \\
\hline 7 & $\begin{array}{l}\text { Formation of acid from } \\
\text { xylose }\end{array}$ & - & - & + & + & + \\
\hline 8 & Motility & - & - & + & + & $+\dagger$ \\
\hline 9 & Pigment + & - & - & + & + & + \\
\hline
\end{tabular}

NT, Not tested.

* Tests 1-4 were made by the methods of Barnes et al. (1956) and test 5 by the method of Shattock (1949). Growth media for tests 1-8 had an initial pH of 7-8.

$\dagger$ Motility was not observed when strain BL $78 / 7$ was grown under nitrogen.

$\ddagger$ The strains recorded as + produced pigment on solidified Medium 1 (initial pH 10.8), but not on Heart Infusion Agar (initial pH 7.4).

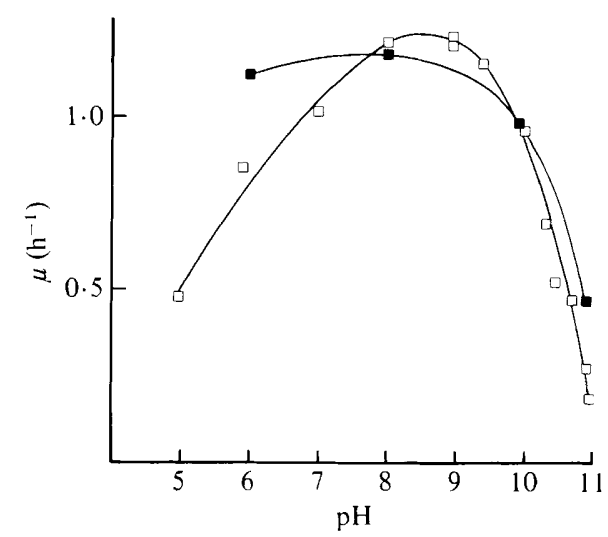

Fig. 1. Effect of $\mathrm{pH}$ on the specific growth rate $(\mu)$ of Streptococcus BL 78/7. Cultures were grown in fermenters in Medium 2 in aerated conditions $(\square)$ with air provided at $800 \mathrm{ml} \mathrm{min} \mathrm{m}^{-1}$ and stirring at 1000 r.p.m., or in non-aerated conditions $(\square)$ with $N_{2}$ bubbled slowly through the medium and stirring at 500 r.p.m. pH was controlled at the values indicated.

\section{Effect of $\mathrm{pH}$ on growth}

The effect of $\mathrm{pH}$ on growth at $37^{\circ} \mathrm{C}$ was studied in batch cultures with continuous control of $\mathrm{pH}$, and growth was observed, without an initial lag phase, at $\mathrm{pH}$ values up to 11 . An exponential increase in $A_{680}$ followed by a sharp cessation of growth occurred at pH 5 to 10.5 , while above 10.5 the growth rate tended to decrease gradually. Organisms tended to occur mainly in pairs for the first 1-2 h of the exponential phase, after which chains were formed, the tendency to form long chains increasing with $\mathrm{pH}$. At $\mathrm{pH}$ values above $10 \cdot 3$, after two to three cell divisions had occurred some chains were twisted or appeared refractile, and above $\mathrm{pH} 10.5$ some cells also appeared swollen and misshapen from late-exponential phase onwards.

In aerated cultures the maximum specific growth rate $(\mu)$ was approximately $1.2 \mathrm{~h}^{-1}$ at $\mathrm{pH}$ values of $8-9$ (Fig. 1) corresponding to a doubling time of $34 \mathrm{~min}$. Growth rates at $\mathrm{pH} 5$ and $\mathrm{pH} 11$ were $0.48 \mathrm{~h}^{-1}$ and approximately $0.2 \mathrm{~h}^{-1}$, respectively. In cultures sparged with nitrogen 


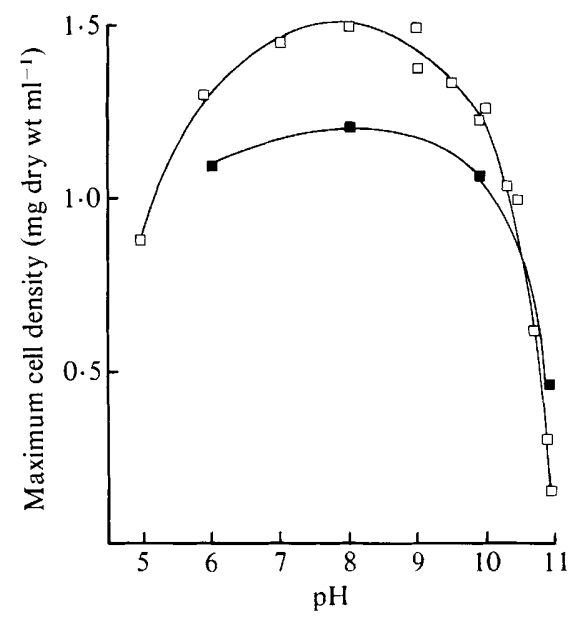

Fig. 2. Effect of $\mathrm{pH}$ on maximum cell density of Streptococcus BL 78/7. Cultures were grown in fermenters in Medium 2 in aerated conditions $(\square)$ with air provided at $800 \mathrm{ml} \mathrm{min}$ m $^{-1}$ and stirring at 1000 r.p.m., or in non-aerated conditions ( $\square$ ) with $\mathrm{N}_{2}$ bubbled slowly through the medium and stirring at 500 r.p.m. pH was controlled at the values indicated.

values for $\mu$ at $\mathrm{pH} 8$ and $\mathrm{pH} 10$ were similar to those determined for aerobic cultures, but at $\mathrm{pH} 6$ a rate of $1.12 \mathrm{~h}^{-1}$ was found, which was significantly higher than the corresponding value for aerated cultures $\left(0.85 \mathrm{~h}^{-1}\right)$. The rates determined at $\mathrm{pH}$ values close to 11 are approximate since a constant rate of growth was not maintained.

The highest cell densities were obtained at $\mathrm{pH}$ values 8 and 9 in aerated cultures $\left(1.5 \mathrm{mg}\right.$ dry wt $\left.\mathrm{ml}^{-1}\right)$ and at $\mathrm{pH} 8$ in cultures under nitrogen $\left(1.3 \mathrm{mg}\right.$ dry wt $\left.\mathrm{ml}^{-1}\right)$ (Fig. 2). The growth rates were also highest at these $\mathrm{pH}$ values. A sharp decrease in maximum cell density occurred at $\mathrm{pH} 10 \cdot 5$. Except at $\mathrm{pH} 11$, cultures grown under aerobic conditions gave slightly higher cell densities than cultures grown under nitrogen.

\section{Effect of pH on metabolic products}

In both aerated cultures and cultures under nitrogen at least $97 \%$ of the total glucose in the medium $\left(27.8 \mu \mathrm{mol} \mathrm{ml}^{-1}\right)$ had been utilized by the beginning of stationary phase at $\mathrm{pH}$ values up to and including $10 \cdot 5$. At $\mathrm{pH}$ values above $10 \cdot 5$, however, growth was not terminated by exhaustion of glucose, only $75-85 \%$ of the available glucose being utilized at pH 11 .

In cultures grown under nitrogen the major products were lactate, formate, acetate and ethanol, the last three occurring in the molar ratio of approximately $2: 1: 1$ (Fig. $3 a$ ). The proportion of lactate formed was highest at low $\mathrm{pH}$, accounting for $86 \%$ of the carbon recovered

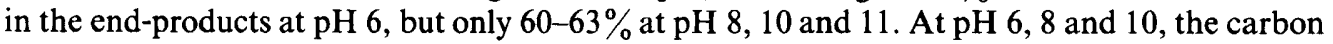
recovered was equivalent to more than $100 \%$ of the glucose present, indicating that medium constituents other than glucose contributed to the products. At pH 11 the carbon recovery was only equivalent to $73 \%$ of the glucose carbon.

In aerated cultures the major products were lactate and acetate (Fig. $3 b$ ). Lactate accounted for $86 \%$ of the carbon recovered at $\mathrm{pH} 5$, and only $47-50 \%$ at $\mathrm{pH}$ values between $10 \cdot 0$ and $10 \cdot 5$. The carbon recoveries were less than $100 \%$ of the glucose carbon at all $\mathrm{pH}$ values, this was probably due to loss of carbon as $\mathrm{CO}_{2}$, which was not trapped.

\section{DISCUSSION}

The isolate BL 78/7 was a group D Streptococcus, apparently of the enterococcus group, but differed from $S$. faecalis, $S$. faecium and $S$. avium in that, under certain conditions, it was motile and pigmented. A similar bacterium was isolated from plant material by Mundt \& Graham (1968) and described as $S$. faecium var. casseliflavus; fermentation of xylose and raffinose were 


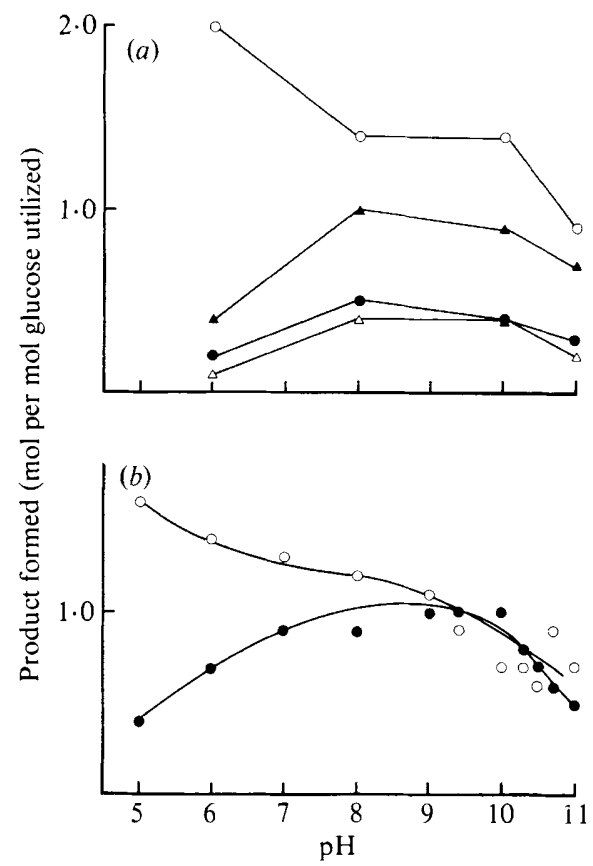

Fig. 3. Effect of $\mathrm{pH}$ on the metabolic products of Streptococcus BL 78/7. (a) Non-aerated culture; (b) aerated culture. Growth conditions as for Figs 1 and 2. Lactate $(O)$; acetate $(O)$; ethanol $(\triangle)$; formate $(\mathbf{\Lambda})$.

further properties in which it differed from the enterococci. Vaughan et al. (1979), from the results of DNA homology studies, proposed that this bacterium was in fact a distinct species. Although in the present work $S$. casseliflavus and strain BL 78/7 did not produce pigment on Heart Infusion Agar, S. casseliflavus was shown by Mundt \& Graham (1968) to form pigment on a variety of non-alkaline media. Strain BL 78/7 resembled $S$. casseliflavus in morphology, pigment and fermentation of raffinose and xylose.

Although tolerance of $\mathrm{pH}$ values up to 9.6 is common in streptococci, the ability to grow at $\mathrm{pH}$ values as high as 11 has not previously been reported. Chesbro \& Evans (1959) reported growth of $S$. faecalis and $S$. faecium at $\mathrm{pH} 10.5$ but growth was preceded by a lag phase of over $12 \mathrm{~h}$, during which the $\mathrm{pH}$ of the medium, which was not controlled, may have fallen. Moreover, the growth rates achieved were lower than those determined for strain $\mathrm{BL} 78 / 7$. The $\mathrm{pH}$ value for optimum growth of strain BL $78 / 7$, approximately 8.5 , was similar to that of another bacterium also isolated from alkaline potato waste (Gee et al., 1980) and subsequently described as Exiguobacterium aurantiacum (Collins et al., 1983). Many alkalophilic bacteria have been reported to have a higher $\mathrm{pH}$ optimum for growth; cultures of Bacillus alcalophilus with malate as a carbon source grew most rapidly at $\mathrm{pH} 10 \cdot 5$ (Guffanti et al., 1978), and a coryneform species (Souza \& Deal, 1977), an Ectothiorhodospira species (Grant et al., 1979) and a Halobacterium species (Tindall et al., 1980), isolated from alkaline springs, grew optimally between $\mathrm{pH} 9$ and 10. These species, however, did not grow at neutral $\mathrm{pH}$, whereas strain $\mathrm{BL} 78 / 7$ was capable of growth at $\mathrm{pH}$ values at least as low as 5 . Such a wide range of $\mathrm{pH}$ tolerance is unusual. The only bacterium previously reported, to our knowledge, with a similar $\mathrm{pH}$ range was a strain of B. sphaericus (Bornside \& Kallio, 1956).

The decrease in growth rate and maximum cell density at $\mathrm{pH}$ values higher than $9 \cdot 5$, despite the fact that at least $97 \%$ of the glucose was utilized at $\mathrm{pH}$ values up to $\mathrm{pH} 10 \cdot 5$, suggests that there is an increase in energy requirement to enable growth at $\mathrm{pH}$ higher than $9 \cdot 5$. The reason for the higher growth rate in non-aerated than in aerated cultures at $\mathrm{pH} 6$ is not known. 
Lactate was the major end-product of metabolism of strain BL $78 / 7$, but the fermentation became increasingly heterolactic with increase in $\mathrm{pH}$. A similar trend in the $\mathrm{pH}$ range 5 to 9 has been reported for $S$. faecalis subsp. liquefaciens (Gunsalus \& Niven, 1942), in the acidic to neutral $\mathrm{pH}$ range for $S$. thermophilus (Platt \& Foster, 1958) and in the $\mathrm{pH}$ range 4 to 8 for Lactobacillus bulgaricus (Rhee \& Pack, 1980). The occurrence, in $\mathrm{N}_{2}$-sparged cultures of strain BL 78/7, of formate, acetate and ethanol in the molar ratio $2: 1: 1$ indicated the involvement of the phosphoroclastic split of pyruvate. In aerated cultures, it appeared that metabolism of pyruvate to acetate and $\mathrm{CO}_{2}$ occurred. As $1 \mathrm{~mol}$ of ATP would be produced during the formation of $1 \mathrm{~mol}$ of acetate from pyruvate the shift from a homolactic to a heterolactic fermentation would be expected to result in an increase in ATP production per mol of glucose utilized. In fact, a similar shift in metabolism has also been reported to occur in Lactobacillus and Streptococcus spp. as a result of glucose limitation (de Vries et al., 1970; Yamada \& Carlsson, 1975; Thomas et al., 1979).

The production in aerated cultures of acetate alone instead of formate, acetate and ethanol, could be due to oxygen sensitivity of the pyruvate formate-lyase enzyme system. In purified extracts from $S$. faecalis the formate-pyruvate exchange enzyme was shown to be highly sensitive to oxygen (Lindmark et al., 1969), and in Enterobacteriaceae the enzyme system is present but inactive in aerobically grown cells (Thauer et al., 1977). In aerated cultures higher cell densities were obtained than in cultures grown under nitrogen. This may be due to the greater quantity of acetate produced aerobically since the production of acetate from pyruvate would generate $1 \mathrm{~mol}$ of ATP per mol of pyruvate, whereas the formation of formate, acetate and ethanol would result in the formation of $1 \mathrm{~mol}$ of ATP per $2 \mathrm{~mol}$ of pyruvate.

The formation of acetate from pyruvate, in contrast to the formation of ethanol, does not regenerate NAD, and since slightly less lactate was produced in aerated than in non-aerated conditions, less NAD would be regenerated by lactate dehydrogenase. It is possible, therefore, that there is an alternative method for the oxidation of NADH in cells grown in aerobic conditions. There is evidence for the presence of a flavin-linked NADH oxidase in $S$. faecium (Ritchey \& Seeley, 1976), and such an enzyme in strain BL 78/7 would remove the necessity for the reduction of pyruvate to oxidize $\mathrm{NADH}$, allowing pyruvate to be used for ATP production by the formation of acetate.

A.F.G. was the recipient of an ARC research studentship.

\section{REFERENCES}

Barnes, E. M., Ingram, M. \& Ingram, G. C. (1956). The distribution and significance of different species of faecal streptococci in bacon factories. Journal of Applied Bacteriology 19, 204-211.

Bornside, G. H. \& Kallio, R. E. (1956). Ureahydrolysing bacilli. I. A physiological approach to identification. Journal of Bacteriology 71, 627-634.

Chesbro, W. R. \& Evans, J. B. (1959). Factors affecting the growth of enterococci in highly alkaline media. Journal of Bacteriology 78, 858-862.

Collins, M. D., Lund, B. M., Farrow, J. A. E. \& SCHLEIFER, K. H. (1983). Chemotaxonomic study of an alkalophilic bacterium, Exiguobacterium aurantiacum gen. nov., sp. nov. Journal of General Microbiology 129, 2037-2042.

De Vries, W., Kapteijn, W. M. C., van der Beek, E. G. \& Stouthamer, A. H. (1970). Molar growth yields and fermentation balances of Lactobacillus casei $\mathbf{L} 3$ in batch cultures and in continuous cultures. Journal of General Microbiology 63, 333-345.

DeIBel, R. H. \& SEeley, H. W. (1974). Streptococcaeceae, In Bergey's Manual of Determinative Bacteriolo$g y$, 8th edition, pp. 490-517 Edited by R. E.
Buchanan \& N. E. Gibbons. Baltimore: Williams and Wilkins.

Deibel, R. H., Lake, D. E. \& Niven, C. F. (1963). Physiology of the enterococci as related to their taxonomy. Journal of Bacteriology 86, 12751282.

Gee, J. M., Lund, B. M., Metcalf, G. \& Peel, J. L. (1980). Properties of a new group of alkalophilic bacteria. Journal of General Microbiology 117, 9-17.

Gee, M., Huxsoll, C. C. \& Graham, R. P. (1974)., Acidification of "dry" caustic peeling waste by lactic acid fermentation. American Potato Journal 51, 126131.

Grant, W. D., Mills, A. A. \& Schofield, A. K. (1979). An alkalophilic species of Ectothiorhodospira from a Kenyan soda lake. Journal of General Microbiology 110, 137-142.

Guffanti, A. A., Susman, P., Blanco, R. \& KrulWICH, T. A. (1978). The protomotive force, and $\alpha$ aminoisobutyric acid transport in an obligately alkalophilic bacterium. Journal of Biological Chemistry 253, 708-715.

Gunsalus, I. C. \& Niven, C. F. (1942). The effect of 
$\mathrm{pH}$ on the lactic acid fermentation. Journal of Biological Chemistry 145, 131-136.

JONES, D. W. \& KAY, J. J. (1976). Determination of volatile fatty acids $\mathrm{C}_{1}-\mathrm{C}_{6}$, and lactic acid in silage juice. Journal of the Science of Food and Agriculture 27, 1005-1014.

Lindmark, D. G., Paolella, P. \& Wood, N. P. (1969). The pyruvate formate-lyase system of Streptococcus faecalis. I. Purification and properties of the formate-pyruvate exchange enzyme. Journal of Biological Chemistry 244, 3605-3612.

Mundt, J. O. \& GRaham, W. F. (1968). Streptococcus faecium var. casseliflavus, nov. var. Journal of Bacteriology 95, 2005-2009.

Platt, T. B., \& Foster, E. M. (1958). Products of glucose metabolism by homofermentative streptococci under anaerobic conditions. Journal of Bacteriology 75, 453-459.

RheE, S. K. \& PACK, M. Y. (1980). Effect of environmental $\mathrm{pH}$ on fermentation balance of Lactobacillus bulgaricus. Journal of Bacteriology 144, 217-221.

Ritchey, T. W. \& Seeley, H. W. (1976). Distribution of cytochrome-like respiration in streptococci. Journal of General Microbiology 93, 195-203.

Shatrock, P. M. F. (1949). The streptococci of group $\mathrm{D}$; the serological refractory group D strains. Journal of General Microbiology 3, 80-92.

Sherman, J. M. (1937). The streptococci. Bacteriological Reviews 1, 3-97.
Sistrunk, W. A., Ismail, M. L. \& Collins, J. A (1979). Bacterial fermentation of high alkaline. wastes from Irish potatoes. Journal of Food Science 44, 439-442.

Souza, K. A. \& Deal, P. H. (1977). Characterization of a novel extremely alkalophilic bacterium. Journal of General Microbiology 101, 103-109.

Thauer, R. K., Jungerman, K. \& DeCKer, K. (1977). Energy conservation in chemotrophic anaerobic bacteria. Bacteriological Reviews 41, 100-180.

Thomas, T. D., Ellwood, D. C. \& Longyear, V. M. C. (1979). Change from homo- to heterolactic fermentation by Streptococcus lactis resulting from glucose limitation in anaerobic chemostat cultures. Journal of Bacteriology 138, 109-117.

Tindall, B. J., Mills, A. A. \& Grant, W. D. (1980). An alkalophilic red halophilic bacterium with a low magnesium requirement from a Kenyan soda lake. Journal of General Microbiology 116, 257-260.

Vaughan, D. H., Riggsby, W. S. \& MundT, J. O. (1979). Deoxyribonucleic acid relatedness of strains of yellow-pigmented, group D streptococci. International Journal of Systematic Bacteriology 29, 204-212.

YAMADA, T. \& CARLSSON, J. (1975). Regulation of lactate dehydrogenase and change of fermentation products in streptococci. Journal of Bacteriology 124, 55-61. 